\title{
KESESUAIAN MUTU DETERJEN CUCI CAIR UNTUK ALAT DAPUR
}

\author{
Quality Fits Detergent of Dishwashing Liquid
}

\author{
Ira Setiawati, Eva Oktarina, dan Auliyah Ariani \\ Balai Besar Kimia dan Kemasan - Kementerian Perindustrian \\ Jl. Balai Kimia No.1, Pekayon, Pasar Rebo, Jakarta Timur, 13069 \\ e-mail:ira.setiawati@gmail.com
}

\begin{abstract}
Abstrak
Bahan kimia memiliki peranan penting dalam kehidupan sehari-hari, diantaranya sebagai deterjen cuci cair untuk alat dapur dengan satu atau lebih jenis surfaktan sebagai komposisi utamanya. Produk deterjen cuci cair untuk alat dapur yang beredar di pasaran harus memiliki mutu sesuai standar yang berlaku sehingga meningkatkan daya saing produk tersebut. Tujuan penelitian ini adalah untuk menentukan jenis-jenis surfaktan yang digunakan dalam deterjen cuci cair untuk alat dapur yang beredar di pasaran dan untukmengevaluasi mutu produk deterjen tersebut berikut kesesuaiannya dengan persyaratan standar yang berlaku yaitu SNI 4075-2:2017 (Deterjen cuci cair - Bagian 2: untuk alat dapur). Metode yang digunakan pada penelitian ini adalah eksploratif kuantitatif yaitu dengan cara mengumpulkan informasi mengenai jenis-jenis surfaktan yang digunakan dalam deterjen cuci cair untuk alat dapur dan melakukan pengecekan mutu produk yang beredar di pasaran (pada wilayah Jakarta, Bekasi, Depok dan Bogor) terhadap pemenuhan persyaratan mutu sesuai SNI 4075-2:2017. Sampel ditelaah kesesuaian mutunya, berdasarkan SNI 4075-2:2017 pada parameter $\mathrm{pH}$, total surfaktan, dan angka lempeng total. Hasil penelusuran komposisi deterjen menunjukkan terdapat satu atau lebih jenis surfaktan yang terkandung dalam deterjen tersebut dan setiap produk memiliki kadar surfaktan yang berbeda-beda. Sedangkan, hasil evaluasi mutu dari deterjen cuci cair untuk alat dapur tersebut memenuhi persyaratan mutu sesuai SNI 4075-2:2017untuk parameter uji total kadar surfaktan dan ALT. Namun, pada parameter uji pH masih terdapat beberapa deterjen yang belum memenuhi persyaratan mutu sesuai SNI 4075-2:2017.
\end{abstract}

Kata kunci: deterjen cuci cair-alat dapur, surfaktan, Standar Nasional Indonesia (SNI).

\begin{abstract}
Chemicals have an important role in daily life, includingdishwashing liquid detergent because it contains one or more types of surfactants as the main composition. Dishwashing liquid detergent products on the market must have quality according to applicable standards thereby increasing the competitiveness of these products. The purpose of this study was to determine the types of surfactants used in theseproducts and to evaluate the quality of these products and its suitability with the applicable standard requirements namely SNI 4075-2: 2017 (Liquid washing detergent - Part 2: for kitchen utensils). The method used in this research is quantitative explorative by collecting information about the types of surfactants used in dishwashing liquid detergent and checking the quality of products on the market (in Jakarta, Bekasi, Depok and Bogor) on compliance quality requirements according to SNI 4075-2: 2017. The samples are examined for suitability of quality, based on SNI 4075-2: 2017 on the parameters of $\mathrm{pH}$, total surfactants, and total plate count. Result of detergent composition tracing show that there are one or more types of surfactants contained in the detergent and each product has different surfactant levels. Meanwhile, the results of the quality evaluation of the dishwashing liquid detergent meet the quality requirements according to SNI 4075-2: 2017 for the test parameters for total surfactant and total plate count levels. However, in the $\mathrm{pH}$ test parameters there are some detergents that do not meet the quality requirements according to SNI 4075-2: 2017.
\end{abstract}

Keywords:dishwashing liquid detergent, surfactant, Indonesian National Standard.

\section{PENDAHULUAN}

Produksi dan konsumsi produk kimia sering digunakan sebagai tolok ukur tingkat kemajuan dan kesejahteraan suatu negara. Hal ini dikarenakan bahwa kehidupan manusia tidak lepas dari pemanfaatan bahan kimia. Bahan kimia yang memiliki peranan penting dalam kehidupan sehari-hari adalah produk pembersih seperti deterjen cuci cair untuk alat dapur atau biasa disebut deterjen cuci piring. Saat ini, produk deterjen cuci piring dengan berbagai macam merek dapat ditemukan di pasaran dan mengandung jenis surfaktan yang berbeda-beda.

Dalam perkembangannya, industri deterjen cuci piring perlu melakukan upaya untuk menghasilkan produk yang berkualitas sesuai dengan standar yang telah ditetapkan. Produk yang sesuai dengan standar akan memiliki nilai tambah dibandingkan dengan 
produk sejenisnya, sehingga dapat meningkatkan daya saing produk tersebut terhadap produk-produk yang ada di pasaran, baik dengan produk lokal maupun produk impor.

Standardisasi merupakan salah satu instrument regulasi teknis yang dapat melindungi kepentingan konsumen nasional sekaligus produsen dalam negeri. Melalui regulasi teknis yang berbasiskan standardisasi, dapat dicegah beredarnya barang-barang yang tidak bermutu di pasar dosmetik khususnya yang terkait dengan kesehatan, keamanan, keselamatan dan pelestrasian fungsi lingkungan hidup. Sehingga, SNI dapat dijadikan sebagai jaminan mutu dari suatu produk. Oleh karena itu, tujuan dari penelitian ini adalah untuk menentukan jenis-jenis surfaktan yang digunakan dalam deterjen cuci cair untuk alat dapur yang beredar di pasaran. Penelitian ini juga bertujuan untuk mengevaluasi mutu produk deterjen tersebut berikut kesesuaiannya dengan persyaratan standar yang berlaku yaitu SNI 4075-2:2017 (Deterjen cuci cair - Bagian 2: untuk alat dapur).

Hasil penelitian ini diharapkan dapat memberikan informasi yang bermanfaat bagi konsumen agar bijak dalam memilih produk, bagi produsen agar menghasilkan produk yang berdaya saing tinggi, aman, berkualitas dan sesuai standar yang berlaku, serta bagi pemerintah sebagai regulator agar dapat memantau dan mengatur produk-produk yang beredar di pasaran baik produk lokal maupun impor.

\section{TINJAUAN PUSTAKA}

Detergen adalah campuran berbagai bahan yang digunakan untuk membantu pembersihan dan terbuat dari bahan-bahan turunan minyak bumi (Samhis, 2019). Deterjen adalah produk pembersih yang efektif karena mengandung satu atau lebih surfaktan atau surface active agent. Surfaktan dalam deterjen diklasifikasikan berdasarkan sifat ioniknya dalam air yaitu anionik, nonionik, kationik dan amfoterik (Anonim, 2019; Shah, 2011). Detergen surfaktan berbeda dengan sabun. Sabun terbentuk dari garam atau asam lemak dan memiliki toksisitas rendah dengan proses pembersihan memanfaatkan reaksi penyabunan atau saponifikasi. Sedangkan detergen merupakan produk pembersih bukan sabun dimana tidak memanfaatkan reaksi saponifikasi seperti halnya sabun dalam proses pembersihan kotoran. Detergen ini dapat berupa granul, cair dan spray (Olson, 2012).

Surfaktan adalah molekul amfifilik yang memiliki gugus hidrofilik atau larut air (gugus kepala) dan gugus hidrofobik, atau gugus tak larut air (gugus ekor). Pada konsentrasi rendah, surfaktan hanya ada sebagai monomer. Pembentukan misel, dimulai pada konsentrasi surfaktan spesifik yang disebut konsentrasi misel kritis (critical micelle concentration, CMC), di mana sifat fisik larutan, seperti tegangan antarmuka, konduktivitas listrik, dan perilaku hamburan cahaya, sering berubah secara tiba-tiba karena keberadaan misel (Shah, 2011; Schramm, 2003).

SNI 4075-2:2017 (Deterjen cuci cair Bagian 2: untuk alat dapur) merupakan revisi dari SNI 06-4075-1996 Deterjen Cuci Cair. SNI 06-4075-1996 hanya menguji surfaktan anionik saja, sedangkan saat ini, surfaktan yang digunakan pada produk deterjen cuci cair sangatlah beragam. Oleh karena itu, pada penelitian ini dilakukan pendataan jenis surfaktan yang digunakan dan mengkaji mutu deterjen berikut kesesuainnya bedasarkan SNI 4075-2:2017. Persyaratan mutu deterjen cuci cair untuk alat dapur dapat dilihat pada Tabel 1.

Tabel 1 Persyaratan mutu SNI 4075-2:2017

(Deterjen cuci cair - Bagian 2: untuk alat

\begin{tabular}{|c|c|c|c|}
\hline No & Kriteria & Satuan & Persyaratan \\
\hline 1 & $\mathrm{pH}, 1 \%$ & - & $3-8$ \\
\hline 2 & $\begin{array}{l}\text { Bahan tidak larut } \\
\text { dalam air }\end{array}$ & $\begin{array}{c}\% \text { fraksi } \\
\text { massa }\end{array}$ & maks. 0,1 \\
\hline 3 & $\begin{array}{l}\text { Total kadar } \\
\text { surfaktan }\end{array}$ & $\begin{array}{l}\% \text { fraksi } \\
\text { massa }\end{array}$ & $\min .10$ \\
\hline 4 & $\begin{array}{l}\text { Specific Gravity } \\
\left(25^{\circ} \mathrm{C} / 25^{\circ} \mathrm{C}\right)\end{array}$ & - & $1,0-1,5$ \\
\hline 5 & $\begin{array}{l}\text { Daya biodegradasi } \\
\text { surfaktan }\end{array}$ & $\%$ & $\min .60$ \\
\hline 6 & $\begin{array}{l}\text { Cemaran mikroba } \\
\text { Angka lempeng } \\
\text { total }\end{array}$ & koloni/g & maks. $1 \times 10^{5}$ \\
\hline
\end{tabular}

Surfaktan sebagai komponen utama dari deterjen akan mempengaruhi karakteristik fisik, kimia dan biologis dari deterjen seperti kadar total surfaktan, $\mathrm{pH}$ dan sifat antimikroba yang ditunjukkan dengan angka lempeng total. Pengujian kadar total surfaktan dilakukan bedasarkan kelarutannya. Bahan yang larut dalam alkohol pada deterjen cair adalah surfaktan (anionik, nonionik, kationik dan amfoterik), alkohol dan parfum. Bahan yang larut dalam eter pada deterjen cair adalah alkohol dan parfum. Sehingga total surfaktan dapat terukur dengan bahan yang larut dalam 
alkohol dikurangi bahan yang terlarut dalam eter.

Jenis surfaktan akan mempengaruhi tingkat keasaman deterjen. Jika digunakan surfaktan jenis kation, maka akan membentuk suasana asam. Sedangkan jika digunakan surfaktan jenis anion, maka akan membentuk suasana basa. Selain itu, surfaktan zwiterionik yang memiliki dua fungsi, bisa menjadi kation atau anion. Surfaktan zwiterionikditentukan oleh $\mathrm{pH}$, apabila $\mathrm{pH}$ asam maka surfaktan ini akan bersifat kation sebaliknya bila dalam suasana basa maka bersifat anion.Surfaktan ini menampilkan muatan dan benar-benar amfoterdi dekat titik isoelektrik (Salager, 2002; Bratovcic et al., 2018).

Surfaktan berfungsi sebagai zat antimikrobadengan mekanisme menghambat kinerja bakteri saat adsorpsi. Surfaktan dapatmempenetrasi ke dalam dinding sel, dan bereaksi dengan membran sitoplasma, sehingga membran pecah dan organel yang berada di dalam sel akan lisis, degradasi protein dan asam nukleat, serta memicu terjadinya autolisis.

\section{METODE PENELITIAN}

Penelitian ini adalah penelitian eksploratif kuantitatif dengan cara mengumpulkan informasi mengenai jenis-jenis surfaktan yang digunakan dalam deterjen cuci cair untuk alat dapur dan melakukan evaluasi mutu produk yang beredar di pasaran terhadap pemenuhan persyaratan mutu sesuai SNI 4075-2:2017. Surfaktan merupakan komposisi utama pada deterjen yang menentukan parameter total surfaktan, $\mathrm{pH}$ dan angka lempeng total.

\section{Pengambilan Contoh}

Contoh detergen cuci cair untuk alat dapur diambil dari pasaran pada April 2019. Lokasi pengambilan contoh adalah toko tradisonal, mini market dan super market di wilayah Jakarta, Bekasi, Depok dan Bogor. Contoh yang diambil sebanyak 12 contoh. Pengambilan sampel dilakukan secara purposive sampling yaitu ditujukan pada produk deterjen cuci cair untuk alat dapur yang mayoritas digunakan masyarakat Indonesia dan tersedia di kota Jakarta, Bogor, Depok, dan Bekasi (JaBoDeBek). JaBoDeBek dipilih karena Jakarta memiliki populasi penduduk yang terbesar di Indonesia yang dikelilingi oleh kota penyangga di sekitarnya yaitu Bogor, Depok, dan Bekasi.

\section{Pengujian Contoh}

Contoh diuji berdasarkan SNI 4075-2:2017 pada parameter $\mathrm{pH}$, total kadar surfaktan, dan angka lempeng total. Metode uji tersebut telah diverifikasi oleh Laboratorium BBKK pada contoh uji deterjen cuci cair-peralatan dapur dan memberikan hasil yang valid.

\section{Pengujian Kadar pH}

Pengujian kadar $\mathrm{pH}$ dilakukan sesuai SNI 4075-2:2017 di Laboratorium Pengujian Kimia Balai Besar Kimia dan Kemasan (BBKK) Kementerian Perindustrian. Contoh uji ditimbang 1 gram dan pindahkan ke dalam labu ukur $1000 \mathrm{~mL}$. Tambahkan air suling bebas $\mathrm{CO}_{2}$ hingga tanda tera, tutup labu ukur dan homogenkan. Tuang larutan ke dalam gelas piala. Diamkan larutan untuk mencapai kesetimbangan pada suhu ruang $(25 \pm 2,0)^{\circ} \mathrm{C}$. Ukur dengan alat $\mathrm{pH}$ meter.

\section{Pengujian Total Kadar Surfaktan}

Pengujian total kadar surfaktan dilakukan sesuai SNI 4075-2:2017 di Laboratorium Pengujian Kimia BBKK Kementerian Perindustrian. Total kadar surfaktan dalam detergen adalah bahan yang larut dalam etanol dikurangi dengan bahan yang larut dalam petroleum eter.

\section{Penentuan zat yang larut dalam etanol}

Contoh uji ditimbang 5 gram dan dimasukkan ke dalam erlenmeyer. Tambahkan $100 \mathrm{~mL}$ etanol $(99,5 \%)$, hubungkan dengan pendingin tegak kemudian panaskan selama 30 menit di atas penangan air sambil sesekali diaduk. Saring larutan hangat dengan menggunakan penyaring dan bilas sisa larutan yang menempel pada erlenmeyer dengan $50 \mathrm{~mL}$ etanol (95\%). Dinginkan filtrat sampai suhu ruang. Pindahkan filtrat ke dalam labu ukur $250 \mathrm{~mL}$ dan tambahkan etanol (95\%) sampai tanda tera. Ambil dengan pipet $100 \mathrm{~mL}$ dan pindahkan ke gelas piala $200 \mathrm{~mL}$ yang telah diketahui bobot kosongnya. Panaskan di atas penangas air untuk menghilangkan etanolnya. Keringkan di dalam oven $(105 \pm 2)^{\circ} \mathrm{C}$ selama 1 jam. Dinginkan dalam eksikator dan timbang sampai bobot tetap.

$$
C_{\mathrm{Et}}=\frac{A}{S \times\left(\frac{100}{250}\right)} \times 100=\frac{250 \times A}{S}
$$

Keterangan:

$\begin{array}{ll}\mathrm{C}_{\text {et }} & : \begin{array}{l}\text { Zat yang larut dalam etanol (\%) } \\ \mathrm{A}\end{array} \\ \mathrm{S} & : \begin{array}{l}\text { Sisa zat setelah pengeringan } \\ \text { Bobot contoh (gram) }\end{array} \\ 100 / 250: & \text { Vol filtrat yang dipipet/vol akhir }\end{array}$


contoh

\section{Penentuan zat yang larut dalam petroleum eter}

Contoh uji ditimbang 10 gram masukkan ke dalam erlenmeyer. Larutkan dalam $200 \mathrm{~mL}$ campuran air-etanol. Saring jika ada bagian yang tidak larut. Tambahkan 0,5 mol/l larutan natrium hidroksida $5 \mathrm{~mL}$, teteskan larutan indikator fenolftalein untuk memastikan bahwa larutan telah basa. Pindahkan ke corong pemisah $500 \mathrm{~mL}$, ekstrak tiga kali dengan 50 $\mathrm{mL}$ petroleum eter, jika emulsi semakin banyak, tambahkan sedikit etanol untuk menghilangkannya. Pada lapisan petroleum eter cuci tiga kali dengan $30 \mathrm{~mL}$ larutan campuran air-alkohol dan cuci dua kali dengan $30 \mathrm{~mL}$ air suling. Keringkan dengan natrium sulfat anhidrat sampai tidak ada lapisan air. Saring dengan menggunakan kertas saring kering yang telah diketahui bobotnya pada erlenmeyer. Uapkan petroleum eter pada penangas air, biarkan labu erlenmeyer di dalam desikator sampai suhu ruang dan timbang sampai bobot tetap.

$$
C_{p e}=\frac{A}{S} \times 100
$$

Keterangan:

$\mathrm{C}_{\mathrm{pe}}$ : Zat yang larut dalam petroleum eter (\%)

A : Jumlah yang terekstraksi dalam petroleum eter (gram)

S : Bobot contoh (gram)

\section{Penentuan total kadar surfaktan}

$$
\text { Total kadar surfaktan, } \%=C_{e t}-C_{p e}
$$

\section{Pengujian Kadar Angka Lempeng Total (ALT)}

Pengujian kadar ALT dilakukan sesuai SNI 4075-2:2017 di Laboratorium Pengujian Mikrobiologi BBKK Kementerian Perindustrian. Contoh uji diencerkan secara desimal (1:10, $1: 100,1: 1000)$. Pipet $1 \mathrm{~mL}$ tiap pengenceran, masukan masing masing ke dalam cawan petri steril secara duplo. Tambahkan 15-20 mL medium TSA dan didinginkan hingga $45^{\circ} \mathrm{C}$. Aduk hingga merata dengan menggoyangkan petri, biarkan membeku pada suhu kamar Inkubasi pada suhu $32^{\circ} \mathrm{C}-35^{\circ} \mathrm{C}$ selama $48-$ 72 jam. Hitung koloni yang tumbuh dengan persamaan sebagai berikut:

$\mathrm{N}=\frac{\sum c}{V x d(n+0,1 n)}$

Keterangan:

$\mathrm{N}$ : Angka Lempeng Total atau Jumlah koloni (koloni/mL)

$\Sigma \mathrm{c}$ : Jumlah koloni yang hidup pada semua cawan petri (koloni)

$\mathrm{V}$ : Volume yang dituangkan pada cawan petri $(\mathrm{mL})$

D : Faktor pengenceran pertama dimana jumlah koloni berada pada kisaran 30300 koloni

$\mathrm{N}$ : Jumlah cawan petri yang jumlah koloninya berada pada kisaran 30-300 koloni

\section{HASIL DAN PEMBAHASAN}

Produk detergen cuci cair untuk alat dapur telah mempunyai Standar Nasional Indonesia (SNI) yaitu SNI 4075-2:2017, tetapi SNI tersebut belum diberlakukan sebagai SNI wajib. Oleh karena itu, perlu dilakukan penelitian untuk mengetahui kesesuaian mutu produk yang beredar di pasaran terhadap standar spesifikasi yang telah ditetapkan.

Detergen cuci cair untuk alat dapur banyak beredar di masyarakat Indonesia, sebagian besar masyarakat menggunakan produk yang tersedia toko tradisional dan toko modern, sehingga pengambilan sampel detergen dalam penelitian ini fokus pada produk tersebut.

Berdasarkan hasil penelusuran terhadap produk deterjen cuci cair untuk alat dapur yang beredar di pasaran tersebut,terdapat satu atau lebih jenis surfaktan yang terkandung dalam deterjen tersebut. Jenisjenis surfaktan yang digunakan oleh industri deterjen cuci cair untuk alat dapur dapat dilihat pada Tabel 2. Kandungan surfaktan tersebut diperoleh dari data yang tertera dalam kemasan. Data tersebut menunjukkan bahwa jenis surfaktan yang digunakan oleh industri sangat bervariasi dalam jenis dan komposisinya. Hal tersebut yang mendasari bahwa pengujian terhadap kandungan surfaktan dilakukan secara total.

Tabel 2 Kandungan surfaktan pada kemasan deterjen cuci cair untuk alat dapur.

\begin{tabular}{cl}
\hline $\begin{array}{c}\text { Kode } \\
\text { Contoh }\end{array}$ & \multicolumn{1}{c}{$\begin{array}{c}\text { Kandungan Surfaktan yang } \\
\text { Tertera di Kemasan }\end{array}$} \\
\hline A & Total surfaktan 18\% \\
B & Total surfactant 20\%: \\
& - LAS-Na (anionik) \\
& - SLES (anionik) \\
& - CAPB (kationik) \\
C & - SLS (anionik) \\
D & SLS (anionik) \\
& - LABSA 12\% (anionik) \\
& - LES emulsifier 4\% \\
& - Cocoamido 0,5\% \\
\hline
\end{tabular}




\begin{tabular}{|c|c|}
\hline $\begin{array}{l}\text { Kode } \\
\text { Contoh }\end{array}$ & $\begin{array}{l}\text { Kandungan Surfaktan yang } \\
\text { Tertera di Kemasan }\end{array}$ \\
\hline & $\begin{array}{l}\text { Kandungan nonionic }+\mathrm{OH} \text { bebas } \\
\text { (cracking powder) }+ \text { Aloe vera } \\
\text { (pelembut tangan) } 6.5 \%\end{array}$ \\
\hline E & Total surfactant $21 \%$ \\
\hline & Antibacterial agent $0,1 \%$ \\
\hline $\mathrm{F}$ & 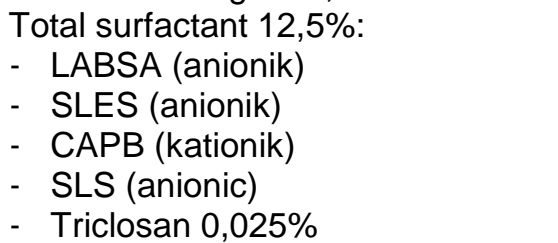 \\
\hline G & SLS (anionik) \\
\hline $\mathrm{H}$ & $\begin{array}{l}\text { - } \quad \text { Biodegradable surfactants } 19 \% \\
\text { - } \\
\text { - }\end{array}$ \\
\hline I & $\begin{array}{l}\text { - Sodium Laureth Sulfate 6,3\% } \\
\text { (anionik) }\end{array}$ \\
\hline & $\begin{array}{l}\text { - Linear Alkyl Benzene Sulfonic } \\
\text { Acid } 4,5 \text { (anionik)\% } \\
\text { - } \quad \text { Hydroxyethyl Laurdimonium } \\
\text { Chloride } 0,5 \%\end{array}$ \\
\hline $\mathrm{J}$ & 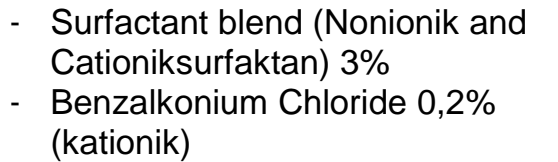 \\
\hline $\mathrm{K}$ & $\begin{array}{l}\text { Total surfactant } 21 \%: \\
\text { - } \text { LAS-Na (anionik) } \\
\text { - } \text { SLES (anionik) } \\
\text { - } \text { CAPB (amfoterik) } \\
\text { - }\end{array}$ \\
\hline $\mathrm{L}$ & $\begin{array}{l}\text { Total surfaktan } 22 \% \\
\text { Sodium salisilat } 0,15 \%\end{array}$ \\
\hline
\end{tabular}

Evaluasi data hasil uji dilakukan terhadap 3 jenis persyaratan mutu yang terdapat pada SNI 4075-2:2017, yaitu $\mathrm{pH}$, total kadar surfaktan dan angka lempeng total. Hasil pengujian ketiga parameter tersebut dapat dilihat pada Tabel 3.

Tabel 3 Hasil pengujian deterjen cuci cair untuk alat dapur.

\begin{tabular}{cccc}
$\begin{array}{c}\text { Kode } \\
\text { Contoh }\end{array}$ & pH(0,1\%) & $\begin{array}{c}\text { Total Kadar } \\
\text { Surfaktan } \\
(\%) / b)\end{array}$ & $\begin{array}{c}\text { ALT } \\
(\text { Kol/mL) }\end{array}$ \\
\hline A & 7,64 & 23,38 & 10 \\
B & 7,97 & 25,07 & $<10$ \\
C & 7,79 & 22,54 & $<10$ \\
D & 7,65 & 22,44 & $<10$ \\
E & 7,64 & 25,15 & $<10$ \\
F & 8,38 & 11,35 & $<10$ \\
G & 8,07 & 17,35 & $<10$ \\
H & 8,64 & 16,60 & $<10$ \\
I & 8,69 & 13,80 & $<10$ \\
J & 7,85 & 17,30 & 10 \\
K & 7,40 & 18,91 & $<10$ \\
L & 8,09 & 15,58 & $<10$ \\
\hline
\end{tabular}

\section{Hasil Pengujian pH}

Pengujian $\mathrm{pH}$ dilakukan sesuai cara uji SNI 4075-2:2017, dengan masing-masing contohdianalisis sebanyak dua kali (duplo). Data hasil uji dapat dilihat di Tabel 2. Secara umum, kadar $\mathrm{pH}$ dalam detergen cuci cair untuk alat dapur di pasaran memenuhi persyaratan mutu SNI4075-2:2017 (Deterjen cuci cair - Bagian 2: untuk alat dapur), namun masih ada beberapa deterjen yang melebihi syarat mutu pada parameter $\mathrm{pH}$ yaitu deterjen pH melebihi persyaratan mutu yang ditetapkan SNI 4075-2:2017 yaitu 3 - 8. Hal ini dapat dilihat pada Gambar 1.

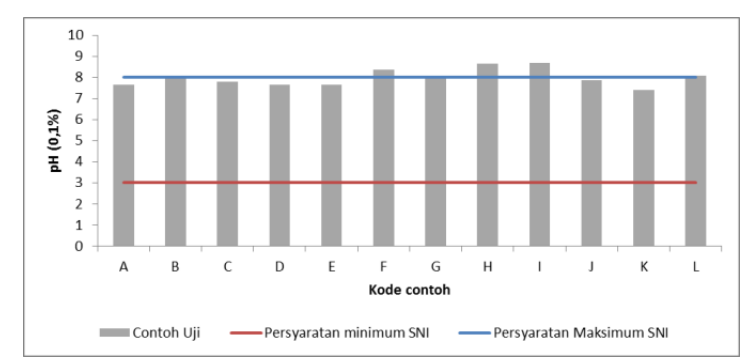

Gambar 1 Kadar $\mathrm{pH}$ dalam detergen cuci cair untuk alat dapur di pasaran.

\section{Hasil Pengujian Total Kadar Surfaktan}

Pengujian total kadar surfaktan dilakukan menggunakan cara uji SNI 4075-2:2017. Masing-masing sampel dianalisis sebanyak dua kali (duplo). Data hasil uji dievaluasi berdasarkan batasan spesifikasi yang dipersyaratakan di SNI. Batasan minimal dalam SNI sebesar $10 \% \mathrm{~b} / \mathrm{b}$ dengan hasil seperti ditunjukkan pada Gambar 2. Seluruh contoh deterjen cuci cair untuk alat dapur sebanyak 12 buah memenuhi standar persyaratan, dengan nilai berada diatas $10 \% \mathrm{~b} / \mathrm{b}$.

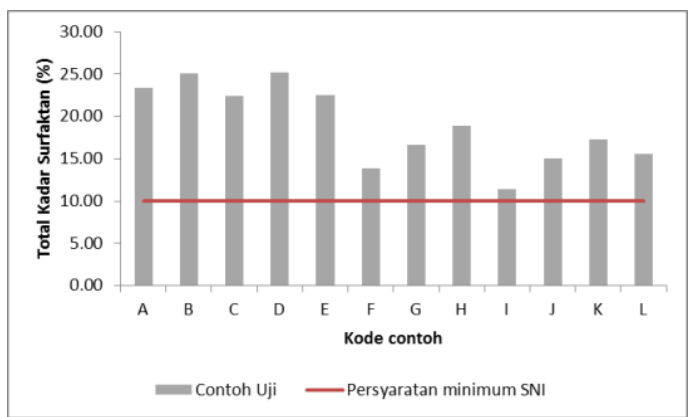

Gambar 2. Total kadar surfaktan detergen cuci cair untuk alat dapur di pasaran.

Surfaktan merupakan kandungan utama dari deterjen sebagai surface active agent yang merupakan zat aktif permukaan dengan dua ujung yang berbeda hidrofil dan hidrofob. Surfaktan berfungsi untuk menurunkan tegangan aktif pada permukaan, antara cairan 
atau antara cairan dan padatan, sehingga kotoran dapat lepas dari permukaan. Surfaktan terdiri dari beberapa tipe yaitu anionik, kationik, amfoterik dan non ionik.

Surfaktan yang paling umum digunakan dalam cairan pencuci piring adalah anionik [alky-lethoxy sulfate $\left(\mathrm{R}\left(\mathrm{OCH}_{2} \mathrm{CH}_{2}\right)_{\mathrm{n}}{ }^{-} \mathrm{OSO}^{-}\right.$ $\left.\mathrm{Na}^{+}\right)$, alkilsulfat $\left(\mathrm{R}-\mathrm{OSO}_{3}^{-} \mathrm{Na}^{+}\right)$, Alkylbenzene sulfonate (R-Ar- $\left.\mathrm{SO}_{3}-\mathrm{Na}^{+}\right)$dan a-olefin sulfonat $\left(\mathrm{R}-\mathrm{CH}_{2}-\mathrm{CH}=\mathrm{CH}-\mathrm{CH}_{2}-\mathrm{OSO}_{3}-\mathrm{Na}^{+}\right)$] dan nonionik [(alkil dimetil aminaoksida( $\mathrm{R}-$ $\left.\left(\mathrm{CH}_{3}\right)_{2} \mathrm{NO}\right)$, alkohol etoksilat $\left(\mathrm{R}\left(\mathrm{OCH}_{2} \mathrm{CH}_{2}\right)\right.$ $\left.{ }_{n} \mathrm{OH}\right)$ dan alkil amida $\left(\mathrm{CH}_{3}\left(\mathrm{CH}_{2}\right)_{n} \mathrm{C}(=\mathrm{O}) \mathrm{N}\right.$ $\left.\left(\mathrm{CH}_{2} \mathrm{CH}_{2} \mathrm{OH}\right)_{2}\right)$ ), serta alkil betaine amfoter (R$\left.\mathrm{N}^{+}-\left(\mathrm{CH}_{3}\right)_{2} \mathrm{CH}_{2}-\mathrm{COO}^{-}\right)$] di mana $\mathrm{R}$ adalah $\mathrm{C}_{\mathrm{x}} \mathrm{H}_{2 \mathrm{x}+1}$ dan $\mathrm{x}$ biasanya dalam kisaran 12-18. Surfaktan anionik adalah pilihan yang sangat baik karena mereka memiliki kinerja pembersihan yang baik dan berbusa sangat baik, di samping biaya rendah dan mudahtersedia. Namun, memiliki beberapa kekurangan, termasuk ketidakcocokan dengan kationik.

\section{Hasil Pengujian Angka Lempeng Total}

Untuk mengetahui cemaran mikroba yaitu Angka Lempeng Total pada contoh uji, maka dilakukan uji sesuai SNI 4075-2:2017 dengan metode pour plate atau cawan tuang menggunakan media penetral CPLP dan media tanam TSA yang mengandung pepton dan kasein sebagai sumber karbonhidrat dan protein.

Hasil dari contoh uji, hampir semua contoh uji tidak ditumbuhi bakteri (0 koloni yang tumbuh pada cawan petri $=<10$ koloni/mL), kecuali sampel $A$ dan $J$ dengan hasil $10 \mathrm{koloni} / \mathrm{mL}$. Hasil tersebut masih memenuhi syarat mutu deterjen cuci cair untuk peralatan dapur SNI 4075-2:2017 yaitu $1 \times 10^{5}$ koloni/mL.

Bakteri tidak tumbuh karena surfaktan memiliki sifat bakterisida dan bakteriostatis. Mekanisme bakterisida surfaktan terhadap bakteri, yaitu: menghambat sintesis dinding sel bakteri, mengganggu membrane sel bakteri; menghambat sintesis protein dan asam nukleat bakteri; serta mengganggu metabolisme sel bakteri. Voss (1963) menyatakan penambahan gugus kation seperti $\mathrm{Na}$ dan $\mathrm{Ca}$ pada surfaktan akan meningkatkan sifat bakterisidal surfaktan. Kation akan menyerang dinding sel bakteri yang umumnya bermuatan negative dan menyebabkan lisis. Selanjutnya, kandungan ABS akan masuk ke dalam sel dan menghancurkan membran sitoplasmik.

Selain itu, beberapa contoh uji mengandung antibacterial agen. Antibacterial agen yang ada pada deterjen dapat berupa triclosan, trichlocarban, kationik ataupun nonionik agen seperti CTAB. Antibacterial agen akan menyerang membran sitoplasmik dan enzim metabolik, sehingga menyebabkan perubahan pada fluiditas dan permeabilitas dari membrane sitoplasmik (Moore 1997). Walaupun saat ini, penggunaan triclosan (TCS) dan trichlocarban (TCC) dikategorikan berbahaya karena dapat meningkatkan resistensi antibiotic, peningkatan resiko penyakit alergi dan merupakan zat yang sulit untuk didegradasi. Saat ini TCS dan TCC dikategorikan pada zat yang not Generally regarded As Effective (not GREA) (Hartono, 2017).

$\begin{array}{llr}\text { Metode } & \text { yang digunakan adalah } \\ \text { penghitungan } & \text { dengan cawan tuang } \\ \text { menggunakan medium pengencer dan }\end{array}$ penetral. Medium yang digunakan adalah Casein Peptone Lecithin Polysorbate 20\% Broth Base, medium ini menggunakan tween 20 dan lecithin yang merupakan zwitterion yang berfungsi untuk menetralkan surfaktan yang digunakan pada contoh uji. Zwitterion memungkinkan contoh uji tercampur dengan medium penetral, sehingga jika terdapat bakteri, memungkinkan bakteri untuk tumbuh.

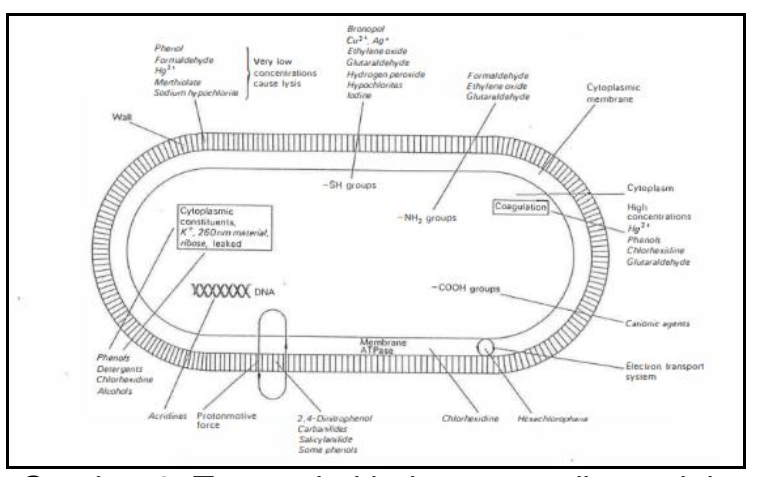

Gambar 3. Target dari beberapa antibacterial agen (Sumber: Moore 1997).

Dari hasil pengamatan pada semua contoh uji, tidak terdapat bakteri yang tumbuh pada cawan petri kecuali pada contoh uji $\mathrm{A}$ dan J, terdapat 1 koloni yang diduga merupakan E. coli. E. coli merupakan bakteri yang sering ditemui pada contoh uji cair. $E$. coli memiliki membrane sel yang hidrofilik. $E$. coli merupakan bakteri gram negative yang lebih tahan terhadap antibacterial agen dibandingkan bakteri gram positif. Hal tersebut karena dinding sel Gram negative mengandung lipopolisakarida, sehingga penetrasi antibacterial agen terbendung (Moore 1997). 


\section{KESIMPULAN}

Deterjen cuci cair untuk alat dapur di wilayah Jakarta, Bekasi, Depok dan Bogor memperlihatkan hasil bahwa:

a. Deterjen cuci cair alat dapur tersebut memiliki satu atau lebih jenis surfaktan yang terdiri dari beberapa jenis yaitu kationik, anionik, amfoterik dan non ionik.

b. Evaluasi mutu dari deterjen cuci cair untuk alat dapur tersebut memenuhi persyaratan mutu sesuai SNI 4075-2:2017untuk parameter uji total kadar surfaktandan ALT. Namun, pada parameter uji $\mathrm{pH}$ masih terdapat beberapa deterjen yang belum memenuhi persyaratan mutu sesuai SNI 4075-2:2017.

\section{DAFTAR PUSTAKA}

Amalia, R., Paramita, V., Kusumayanti, H., Wahyuningsih, Sembiring, M., Rani, D. E. (2018). Produksi sabun cuci piring sebagai upaya peningkatan efektivitas dan peluang wirausaha. Metana, 14 (1), 15-18.

Anonim (2019). Mengenal detergen di rumah tangga. [Get to know detergents in the household] Retrieved June 11, 2019 from

http://ik.pom.go.id/v2016/artikel/Mengen alDetergendiRumahTangga.pdf

Badan Standardisasi Nasional. (2017). SNI 4075-2:2017 Detergen Cuci Cair Bagian 2: Untuk Alat Dapur. Jakarta.

Blagojevic, S. N., Blagojevic, S. M., \& Pejic, N. D. 2016. Performance and efficiency of anionic dishwashing liquids with amphoteric and non-ionic surfactants. Journal of Surfactants and Detergents, 19, 363-372.

Bratovcic, A., Nazdrajic, S., Odobasic, A., \& Sestan, I. 2018. The Influence of Type of Surfactant on Physicochemical Properties of Liquid Soap. International Journal of Material and Chemistry, 8(2), 31-37.

De, S., Malik, S., Ghosh, A., Saha, R., \& Saha, B. (2015). A review on natural surfactants. Royal Society of Chemistry Advances, 5, 65757-65767.

Fatoni, R. dan Fatimah, S. (2017). Pengembangan ekonomi kreatif melalui pembuatan sabun cair; sebuah upaya pemberdayaan anggota Aisyiah di wilayah Solo Raya. The $6^{\text {th }}$ University Research Colloquium, Universitas Muhammadiyah Magelang, 149-152.
Farn, R. J. (2006). Chemistry and Technology of Surfactants. UK: Blackwell Publishing.

Hartono, I. (2017). Bahaya kandungan triclosan dan triclocarban pada sabun antiseptic. [Danger of the content of triclosan and triclocarban on antiseptic soap]. Retrieved May 27, 2019 from : http://www.alomedika.com/bahayakandungan-triclosan-dan-triclocarbanpada-sabun-antiseptic

Kosaric, N. 2001. "ChemInform Abstract: Biosurfactants." Food. Technol. Biotechnol. 39 (4): 295-304. https://doi.org/10.1002/chin.199112362.

Moore, S.L. (1997). The Mechanisms of Antibacterial Action of Some Nonionic Surfactants. Thesis of The University of Brighton. Port Sunlight.

Myers, D. 2008. Surfactant science and technology. John Wiley \& Son Inc., New Jersey.

Olson, K. R. (2012) Poisoning and drug overdose, 6th edition. USA : The McGraw-Hill.

Prameswari, N. S., Suharto, M., \& Wulandari, E. (2018). Strategi branding melalui inovasi desain kemasan bagi home industry sabun cair. Jurnal Desain Komunikasi Visual, Manajemen Desain, dan Periklanan, 3 (2), 35-54.

Pusat Kebijakan Perdagangan Dalam Negeri. 2015. Kajian peranan SNI untuk penguatan pasar dalam negeri dan daya saing produk ekspor. Kemendag.

Rumondang, I. dan E. Oktarina. Kajian surfaktan dalam standarisasi deterjen cair untuk menghadapi pasar global. 2015. Prosiding PPIS.

Salager, J. L. (2002). Surfactants - Types and Uses. Venezuela: Laboratorio FIRP, Universidad de Los Andes.

Samhis, S. (2019). Detergen - Pengertian dan jenis komposisi pembuat. Retrieved June 11, 2019 from https://www.gurupendidikan.co.id/ detergen-pengertian-jenis-komposisibahan-pembuat

Schramm, L. L, Stasiuk, E. N., \& Marangoni, D. G. (2003). Surfactants and their applications. Annu. Rep. Prog. Chem., Sect. C, 99, 3-48.

Shah, S.K.,Bhattarai, A.,Chatterjee, S.K. (2011). Surfactants, its application and effect on environment.Bibechana AMultidisciplinary Journal of Science Technology and Mathematics, 7, 61-64.

Voss, J.G. (1963). Effect of inorganic cation on bactericidal activity of anionic surfactants. J. Bacteriol., 86. 
